\title{
Ventilator-induced lung-injury in mouse models: Is there a trap?
}

\author{
Jon Petur Joelsson 1,2,4*0 , Saevar Ingthorsson ${ }^{2,3}$, Jennifer Kricker ${ }^{4}$, Thorarinn Gudjonsson ${ }^{1,2,4}$ and \\ Sigurbergur Karason ${ }^{1,5}$
}

\begin{abstract}
Ventilator-induced lung injury (VILI) is a serious acute injury to the lung tissue that can develop during mechanical ventilation of patients. Due to the mechanical strain of ventilation, damage can occur in the bronchiolar and alveolar epithelium resulting in a cascade of events that may be fatal to the patients. Patients requiring mechanical ventilation are often critically ill, which limits the possibility of obtaining patient samples, making VILI research challenging. In vitro models are very important for VILI research, but the complexity of the cellular interactions in multi-organ animals, necessitates in vivo studies where the mouse model is a common choice. However, the settings and duration of ventilation used to create VILI in mice vary greatly, causing uncertainty in interpretation and comparison of results. This review examines approaches to induce VILI in mouse models for the last 10 years, to our best knowledge, summarizing methods and key parameters presented across the studies. The results imply that a more standardized approach is warranted.
\end{abstract}

Keywords: Ventilator-induced lung injury, Mouse studies, Animal models, Acute lung injury

\section{Background}

Mechanical ventilation (MV) of patients may be required for various reasons but the main applications in critically ill patients are alleviating work of breathing and ensuring sufficient gas exchange during the resolution of the underlying disease. It has been established, however, that ventilation treatment may harm the lung and increase mortality [1].

During normal inspiration, air flows into the lungs due to negative pressure generated in the thorax by expanding the lungs via contraction of the diaphragm and intercostal muscles. During MV, the opposite occurs, air is thrust into the lungs with the use of positive pressure from the ventilator, which can lead to damage of the lung

\footnotetext{
*Correspondence: jpj@hi.is

1 Stem Cell Research Unit, BioMedical Center, School of Health Sciences,

University of Iceland, Reykjavik, Iceland

Full list of author information is available at the end of the article
}

epithelium due to mechanical strain, named ventilatorinduced lung injury (VILI) [2].

Consequently, MV can exacerbate respiratory failure in already diseased lung tissue, or even be the primary cause of it through VILI in healthy lungs if they are recklessly ventilated. If adequate positive end-expiratory pressure (PEEP) is not used, the alveoli will collapse during expiration and then be reopened forcefully and repeatedly with each inspiration rendering them susceptible to shear stress and injury in what is called atelectrauma (Fig. 1A). During inspiration, if pressure and/or volume is inappropriately high, open alveoli may be subjected to over-distension and damaged in what is termed volu/barotrauma (Fig. 1B). Additionally, in severe respiratory failure, a high fraction of oxygen in inspiratory air is usually used that can increase the oxidative stress of the tissue and cause cell injury. Cumulatively, these damage-inducing factors can lead to an initial activation of local immune response in the lung tissue, causing a cascade effect resulting in an excessive immune response and overflow of 


\section{Ventilator-Induced Lung Injury}

A.

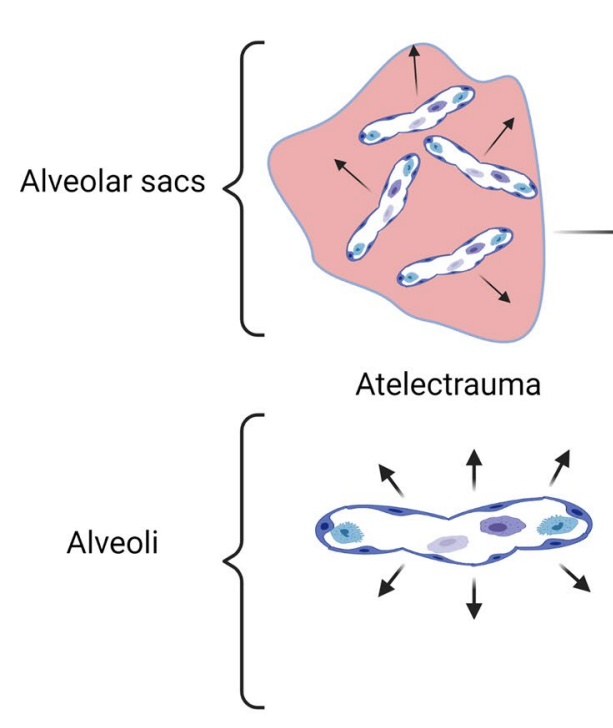

B.

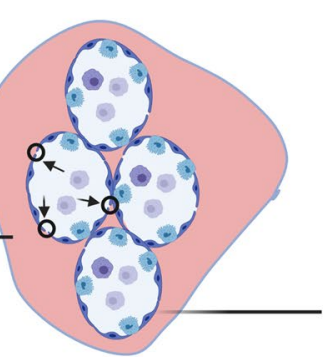

Volu/barotrauma

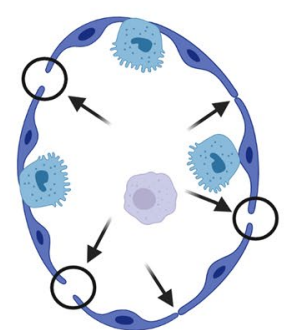

C.

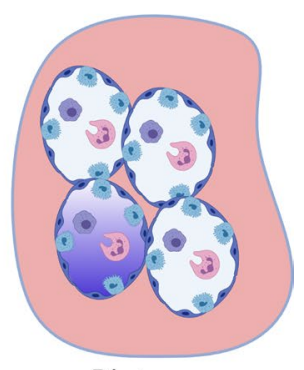

Biotrauma

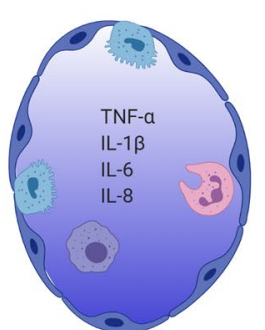

Fig. 1 Ventilator-induced lung injury. A Mechanical ventilation with insufficient PEEP can lead to collapse of the alveoli, leading to atelectrauma. Inspiration and expiration from the mechanical ventilator will lead to the alveoli being repeatedly opened and collapsed, which will lead to shear stress and injury. B Inappropriately high pressure/tidal volume settings from the mechanical ventilator can lead to overdistension of the distal bronchi and alveoli, leading to volu/barotrauma injury and barrier disruption. C The damage caused by atelectrauma and volu/barotrauma cumulatively can lead to activation of immune and epithelial cells, causing an excessive inflammatory response which can lead to an influx of inflammatory mediators (TNF-a, IL-1 $\beta$, IL-6 and IL-8), resulting in what is called biotrauma. Figure created with BioRender.com

inflammatory parameters into the bloodstream affecting other organs, in what is termed biotrauma (Fig. 1C) [3].

Clinical research on VILI in patients is challenging due to the high-risk nature of invasive diagnostic procedures in patients with serious respiratory failure. Access to patient lung samples is therefore limited, effectively restricting research to either healthy tissue or end-point samples; emphasizing the need for alternative methodologies such as in vitro research, or in vivo animal models.

In vitro models of VILI are few and physiologically limited. The lung is a complex organ and contains several epithelial, interstitial, and immune cell types arranged in a wide variety of tissues within the organ, which is extremely difficult to recapitulate in vitro [4]. Cell models usually do not adequately represent the mechanical forces that lung tissues and cells in vivo are subjected to. Our laboratory has, however, recently established a novel in vitro system to mimic VILI in lung epithelial cells cultured in air-liquid interface conditions, using the cyclical pressure air-liquid interface device (CPAD) [5]. Employing the CPAD, we were able to mimic important events in
VILI by inducing barrier damage in bronchial and alveolar epithelial cell layers. We showed that azithromycin treatment protected the epithelial layer against mechanical strain by maintaining the actin structures of the cytoskeleton, changing lipid metabolism, and attenuating inflammatory responses [6]. In vitro systems are useful to gain an initial indication of relevant mechanisms but they lack the complex epithelium, stroma and the microvasculature interactions. Therefore, translation of results from in vitro studies to clinical usefulness requires testing in in vivo models.

Mice have been extensively used to study VILI. However, there is no standardized model for establishing VILI in mice in the literature and important parameters of ventilator configurations and settings in published papers vary considerably. These key parameters include choice of tidal volume, time of ventilation, breaths per minute, use of protective ventilation strategies such as PEEP, choice of anesthetic drugs, type of animal used, and whether it is appropriate to base the ventilation on pressure or tidal volume generated by the mechanical 
ventilator. Such variation creates difficulties in reproducing an equivalent, robust model, as well as interpretation and comparison of results.

In 2010, the American Thoracic Society published a workshop report with a consensus of the main features characterizing acute lung injury (ALI) in animal models and identified the most relevant methods to assess these features [7]. These methods were categorized based on relevance regarding tissue injury, capillary barrier function, inflammatory response and physiological dysfunction. The report was intended as a guide for researchers to choose appropriate measurements best suited for their experimental questions.

The purpose of this review is to summarize information from in vivo VILI experiments in mice conducted over the last decade, highlighting the range of ventilator modes and settings and selection of mice strains, then identifying advantages and disadvantages of various experimental set ups. Such information should assist researchers in choosing ventilator configurations appropriate for their studies, enabling a more standardized approach towards certain research questions allowing easier interpretation and comparison of results.

A PubMed search was conducted with the search term "ventilator induced lung injury mouse model", filtering the publication year from 2010 to 2020 . From the 372 matching hits, we concentrated on models where mice were mechanically ventilated, leaving a pool of 99 publications [8-106]. Figure 2 shows the distribution of the publications over the 10 years. Each article was reviewed in depth and information on various parameters identified and key information listed in a table (Additional file 1: Table S1).

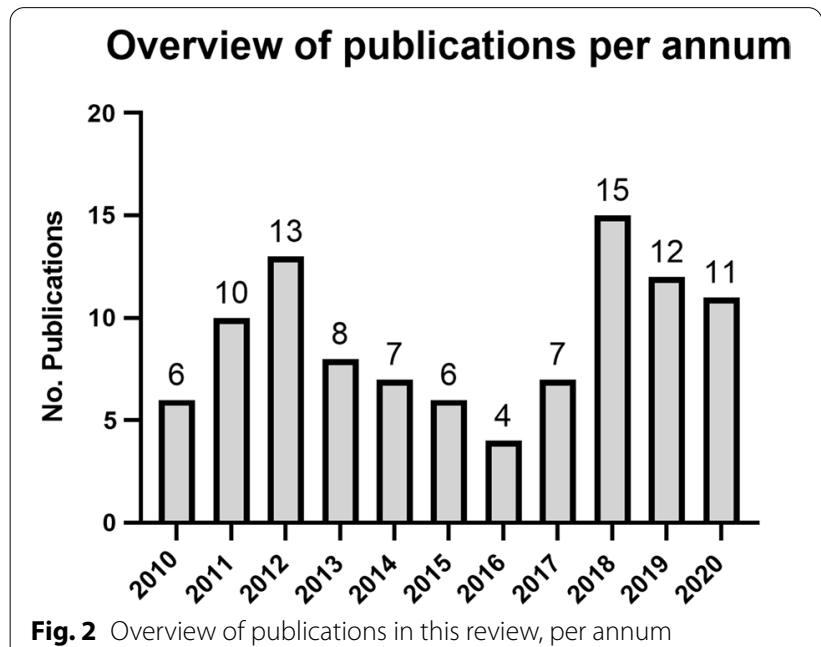

\section{Main text}

Mouse strains

Animal models, especially mouse strains, are vital in biomedical research as they bridge basic research from the in vitro to the in vivo clinical setting. There are many mouse strains available for biological research. Inbred mouse strains are genetically homologous, thereby reducing the risk of variation in the results, while outbred stocks such as CD-1 represent heterozygous populations and higher variability in the results. The choice of mouse strain to use for an experimental application depends on the research question being addressed. In the case of lung health, the test animals' response to stress and damage should not be compromised, but it is critical that the animals are capable of generating a strong immune response, as inflammation is the premise for VILI. In this regard, mouse strains that are immunodeficient, such as CB17SCID mice are preferred for studying cancer biology and cancer treatment strategies, but they are suboptimal for studying normal pathophysiology, for example lung physiology.

One of the most popular mouse strains for research is the C57BL/6. These black inbred mice are a stable strain and easily bred. They represent the majority of the mice used for VILI research covered in this review (Fig. 3) C57BL/6 mice are known for their immunogenicity as they were initially bred for antitumor and immunological research purposes [107]. Several repositories

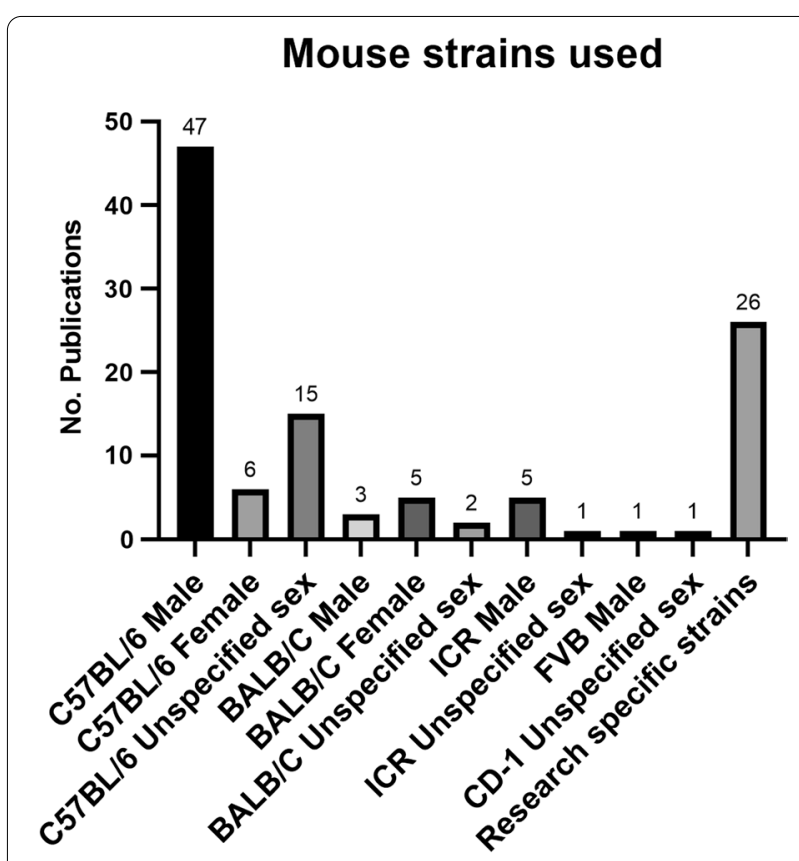

Fig. 3 Overview of mouse strains used in the reviewed publications per annum. Often, more than one strain was used 
breed C57BL/6 mice, including Jackson Laboratories (C57BL/6J) and Taconic (C57BL/6Tac). These breeding colonies have been genetically isolated for tens or hundreds of generations and due to genetic drift have become genetically different from one another; a fact that needs to be considered when choosing animals for studies [108]. In the selected papers on VILI, 68 instances of mouse strain selected were for C57BL/6. Of those, 47 were male and 6 female and in 15 studies, the sex was not specified in the methods.

BALB/c mice are also a popular choice for VILI studies. BALB/c mice are an inbred, immunodeficient, albino mouse strain. They are easily bred but tumor-prone [109]. In the publications checked, BALB/c mice were used in 10 instances and of those, 3 were male, 5 were female and 2 were not specified. Other mouse strains to note were ICR, sensitive A/J and CD-1 strains. Twentysix strains were specifically attained or bred for the VILI research in question. These include TRPM -/-, NLRP3 -/- [82], Src-deficient [55], Tpl2 -/- [47], RAGE KO [48], TNF receptor $2 \mathrm{KO}$ [68], TLR4 KO [66], TRPV4deficient [65], gpl1 $+/-$ and Sphk1 -/- [76], Zmpste24 -/- and Lmna LCS/LCS [73], IL6 -/- [16, 45], Muc5ac-deficient [39] and Akt +/- [18]. In 4 instances neither the strain nor sex of the mice were specified. A thorough overview over different mouse strains can be found at Labome [110].

Besides mouse strain and gender, age was also highly variable. To simplify our summary, we categorized the mice into the following age groups with the number of instances in parentheses: $3-6$ weeks (2); 6-8 weeks (16); 8-12 weeks (40); 12-16 weeks (7); 16-18 weeks (1) (Fig. 4). Only one publication used neonatal mice. Although the 8-12 weeks age range, young adult mice, was most widely used, there did not appear to be a consensus of optimal age. Moreover, the age of the mice was not specified in 35 of the publications.

The weight of the mice was largely consistent with their respective ages, but this could not always be ascertained as 49 of the publications on VILI did not state the weight of the mice specifically. The weight range was mostly within $20-25 \mathrm{~g}$ with the lowest being $17.1 \mathrm{~g}$ and the highest being $30 \mathrm{~g}$.

\section{Ventilator settings}

Positive pressure ventilation has been used to treat patients for more than six decades [111]. However, it is still debated how such treatment can be optimized as there are no clinical methods to individualize the treatment but only empirical guidelines on how to set the ventilator [112]. There has been an emphasis in recent years on using protective lung ventilation (PLV) for all patients undergoing ventilator treatment in order to avoid VILI,

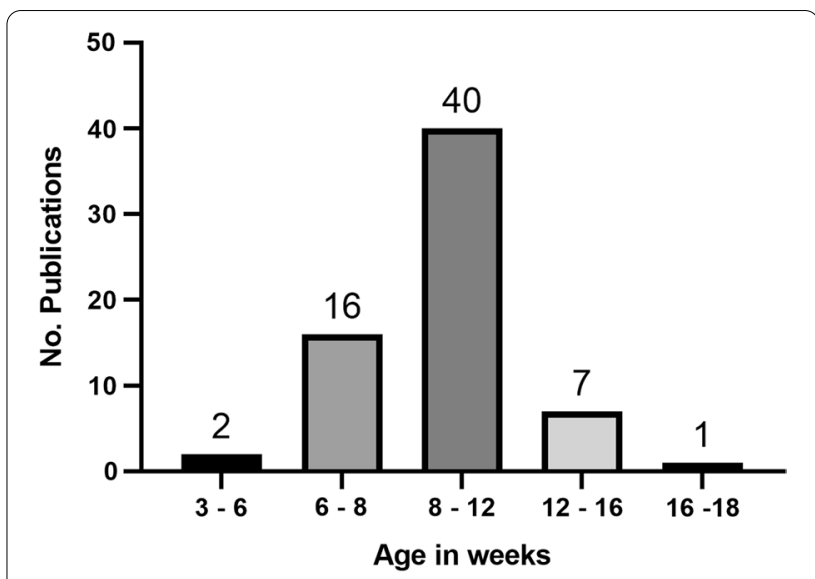

Fig. 4 Overview of the age range of mice in the reviewed publications

even in those with healthy lungs. The purpose of PLV is to keep the mechanical strain as low as possible to prevent VILI using the following principles: (1) using a low tidal volume between 4 and $8 \mathrm{~mL} / \mathrm{kg}$ according to predicted body weight, (2) keeping peak or plateau pressure below $30 \mathrm{~cm} \mathrm{H}_{2} \mathrm{O}$, (3) setting PEEP according to the severity of the respiratory failure, usually not higher that $10-15 \mathrm{~cm} \mathrm{H}_{2} \mathrm{O}$ in adults with severe respiratory failure, (4) keeping the driving pressure (the pressure difference between end-inspiration (plateau pressure) and end-expiration (PEEP)) below $15 \mathrm{~cm} \mathrm{H}_{2} \mathrm{O}$; and (5) adjusting the respiratory rate to keep $\mathrm{PaCO}_{2}$ within satisfactory limits but preferably keeping the blood $\mathrm{pH}$ between 7.3 and 7.45 and respiratory rate below 35 per minute $[1,113]$.

If it is not possible to ensure sufficient gas exchange within these limits, other measures may be considered, such as prone position to increase gas exchange in the lungs or extracorporeal devices, such as extracorporeal $\mathrm{CO}_{2}$ removal $\left(\mathrm{ECCO}_{2} \mathrm{R}\right)$ or extracorporeal membrane oxygenation (ECMO) [114]. Even though it is possible to preserve sufficient gas exchange within the recommended settings of PLV, some individuals may be subjected to VILI over time, especially those at risk for, or already exhibiting acute respiratory distress syndrome (ARDS) [2].

The target for MV can be either tidal volume (using constant flow) or airway pressure (using decelerating flow) but neither has been shown to be superior in terms of outcome [115]. In current computerized ventilators, a mixture of both is often used, i.e. a tidal volume is set but the ventilator uses decelerating flow to provide the required volume with as low airway pressure as possible.

In order to induce an appropriate level of VILI in mouse models, it is necessary to choose appropriate parameters for the ventilation. This includes the amount 
of airway pressure or tidal volume, duration of ventilation, and respiratory rate. The cumulative strain on the lung tissue is the sum of the driving pressure and respiratory rate [111].

Determining how much pressure or tidal volume to use in an experiment simulating VILI is vital to its outcome. Using too little pressure or tidal volume would result in very mild injury and would unlikely lead to significant results. On the other hand, using too much pressure or tidal volume would result in a too severe injury which is not representative of clinical reality. In either case, this would be a regrettable waste of animals. Any efforts to standardize these parameters to sufficiently recapitulate VILI in an experimental animal should therefore be of great importance, both ethically and scientifically.

Of the 99 publications on VILI we selected, 72 used tidal volume $(\mathrm{mL} / \mathrm{kg})$ as a parameter for the mechanical ventilator and 13 used pressure $\left(\mathrm{cm} \mathrm{H}_{2} \mathrm{O}\right)$. Fourteen of the publications used both. Tidal volume-based terminology used in the publications varied greatly, emphasizing the need for standardized definitions. "Low" was used in 24 instances and ranged between 6 and $7.5 \mathrm{~mL} / \mathrm{kg}$, "protective" was used in 4 instances for $6-10 \mathrm{~mL} / \mathrm{kg}$ and "gentle" in one at $8 \mathrm{~mL} / \mathrm{kg}$. Four publications used "normal" designation with a range of 6-10 $\mathrm{mL} / \mathrm{kg}$ and "moderate" was used in 2 publications at a range of $10-12 \mathrm{~mL} /$ $\mathrm{kg}$. In the higher ranges, "injurious" was used 5 times in the $15-25 \mathrm{~mL} / \mathrm{kg}$ range and "aggressive" used in one at $15 \mathrm{~mL} / \mathrm{kg}$. "High" was used in 25 instances at a range of $12-47 \mathrm{~mL} / \mathrm{kg}$, with the most common value used being $30 \mathrm{~mL} / \mathrm{kg}$. As for the publications that used pressure target for ventilations, "low" was used at pressures of 8-15 cm $\mathrm{H}_{2} \mathrm{O}$ in 6 instances and "high" at 20-50 $\mathrm{cm} \mathrm{H}_{2} \mathrm{O}$ in 6 instances, while "injurious" was used once at $27 \mathrm{~cm}$ $\mathrm{H}_{2} \mathrm{O}$. The majority of articles did not designate a specific term for the tidal volume or pressure as anything other than the values listed.

PEEP is a widely used method in the clinic with the purpose of enhancing gas exchange, increasing functional residual capacity (FRC) and avoiding atelectrauma [116]. Twenty-two of the publications used 0 PEEP for their experiments, while 49 used PEEP at values from 1 to $8 \mathrm{~cm} \mathrm{H}_{2} \mathrm{O}$, with $2-3 \mathrm{~cm} \mathrm{H}_{2} \mathrm{O}$ being most commonly used. Twenty-seven publications did not specify whether they used PEEP or not.

Another aspect of ventilation that needs to be considered is the breathing frequency [1]. If the same breathing frequency is maintained during normal ventilation and injurious ventilation with high tidal volume, the animal will become hyperventilated, potentially affecting circulation and acid-base homeostasis during injurious ventilation. It is therefore necessary to decrease the respiratory rate when high tidal volumes are used to avoid excessive ventilation, if the aim is mainly to study the mechanical strain.

Generally across the publications, breaths per minute were usually set lower for the higher tidal volume/pressure settings, presumably to lower the risk of excessive hyperventilation and subsequent hypocapnia and alkalosis. Considering, for this review, that tidal volume under $20 \mathrm{~mL} / \mathrm{kg}$ and airway pressure $25 \mathrm{~cm} \mathrm{H}_{2} \mathrm{O}$ or lower falls into the category of lower ventilation and everything above these values is considered higher, then breaths per minute in the lower category were reported in 58 instances at 40-225, with the average being at around 120. In the higher category there were reported 63 instances at 30-160 breaths per minute with an average of around 70. Nineteen of the publications did not mention breaths per minute in the ventilated animals.

During ventilator treatment in the ICU, respiratory rate is usually set between 14 and 22 breathes/min creating a 'per minute ventilation', with the set tidal volume, of 6-10 $\mathrm{L} / \mathrm{min}$ with the aim of keeping $\mathrm{PaCO}_{2}$ and $\mathrm{pH}$ within acceptable limits. The ratio of oxygen is kept as low as possible to keep normal blood saturation within 92-98\% [111].

Another parameter in creating an effective VILI model is the duration of ventilation, which should be sufficient to achieve the desired response. Ventilating the mice for too long at high pressure or tidal volume will likely result in the death of the animal $[90,117]$. In the publications reviewed here, there were many instances of more than one ventilation time indicated, but for the sake of this review only the higher values were selected. In that fashion, the average time of ventilation was approximately $4.4 \mathrm{~h}$. The most common ventilation time was $4 \mathrm{~h}$, which was applied in 41 of the publications. Two publications reported ventilation until death of the animal, while 9 publications did not specify the duration of ventilation.

Interestingly, in all the publications that mentioned method of intubation (73 out of the 99), the mice were tracheotomized and intubated through the trachea. The reasons for tracheotomy over oral intubation of mice is presumably due to technical issues; mice are small animals and oral access to the trachea is problematic, especially in smaller mice.

\section{Anesthesia}

VILI research is most often end-point related, meaning that the mice will be sacrificed after the ventilation. As such, general anesthesia is used and choosing the right drugs for anesthesia is crucial. Minimizing the distress and suffering of the animals is of utmost importance, both for ethical reasons, as well as for the potential influence on the experiments. A comprehensive review of mouse anesthesia was published by Gargiolu et al. [118]. 
In our review of the 99 publications, the most commonly used anesthesia agent was a combination of ketamine/xylazine, (40 of the publications). Ketamine concentrations, when stated, ranged from 50 to $200 \mathrm{mg} /$ $\mathrm{kg}$ with the average being $100.1 \mathrm{mg} / \mathrm{kg}$. Xylazine concentration ranged from 0.8 to 40 with the average being $11.8 \mathrm{mg} / \mathrm{kg}$. Ketamine was also used in combination with acepromazine (average $1.1 \mathrm{mg} / \mathrm{kg}$ ), dexmedetomidine (average $0.1 \mathrm{mg} / \mathrm{kg})$, atropine $(0.5 \mathrm{mg} / \mathrm{kg}$ and $10 \mu \mathrm{g} / \mathrm{kg}$ ) and fentanyl (50, 90 and $120 \mu \mathrm{g} / \mathrm{kg})$. Pentobarbital sodium was used in 18 of the publications at concentrations of $20-90 \mathrm{mg} / \mathrm{kg}$ (except for in one publication where it is stated as $90 \mu \mathrm{g} / \mathrm{kg}$ ) with the average being $59.7 \mathrm{mg} / \mathrm{kg}$. Zoletil was used in 4 publications at 5 (supplemented with $5 \mathrm{mg} / \mathrm{kg}$ of xylazine), 5, 50 (supplemented with $5 \mathrm{mg} / \mathrm{kg}$ of xylazine) and $80 \mathrm{mg} / \mathrm{kg}$ concentrations. Fentanyl/medetomidine/midazolam was used in 2 publications at $0.05 / 0.5 / 5 \mathrm{mg} / \mathrm{kg}$ concentrations, respectively, in one and at $0.075 / 0.75 / 1.5 \mathrm{mg} / \mathrm{kg}$ in the other. Celecoxib was used once at 20 or $40 \mathrm{mg} / \mathrm{kg}$ and avertin in one at $250 \mathrm{mg} / \mathrm{kg}$. Of the 99 publications reviewed here, $18 \mathrm{did}$ not specify type of anesthesia employed.

\section{Assays to measure VILI}

Many of the assays used in the publications reviewed were highly specific to the research question addressed. However, there was a level of consensus in the methodologies used, including analysis of bronchial alveolar lavage fluid (BALF) (cytokine measurement and neutrophil counting), total protein concentration along with individual protein assays, cytokine increases (Most specifically IL-1 $\beta$, IL-6, IL-8 and TNF $\alpha$ ), wet-dry ratio of the lungs, $\mathrm{H} \& \mathrm{E}$ histology analysis, immunohistochemical measurements, and injury scoring. According to the official workshop report of the American Thoracic Society [7], the main features of experimental ALI in animals are histological evidence of tissue injury, alteration of the alveolar capillary barrier, inflammatory response, and evidence of physiological dysfunction. The reviewed VILI publications were scanned with these criteria in mind. Figure 5 illustrates how these criteria are represented in the reviewed publications and how they overlap.

Measuring histological evidence of tissue injury included counting infiltrating neutrophils and measuring lung damage in a standardized manner. Histological assessments were reported in 75 of the 99 publications.

Measurements of the alveolar capillary barrier includes measuring total protein concentration in BALF, increase in lung wet/dry ratio and Evans Blue permeability assays. Seventy-two of 99 publications employed some of these methods to measure barrier integrity.

Increased inflammatory response was reported as an increase in neutrophil or myeloperoxidase concentrations

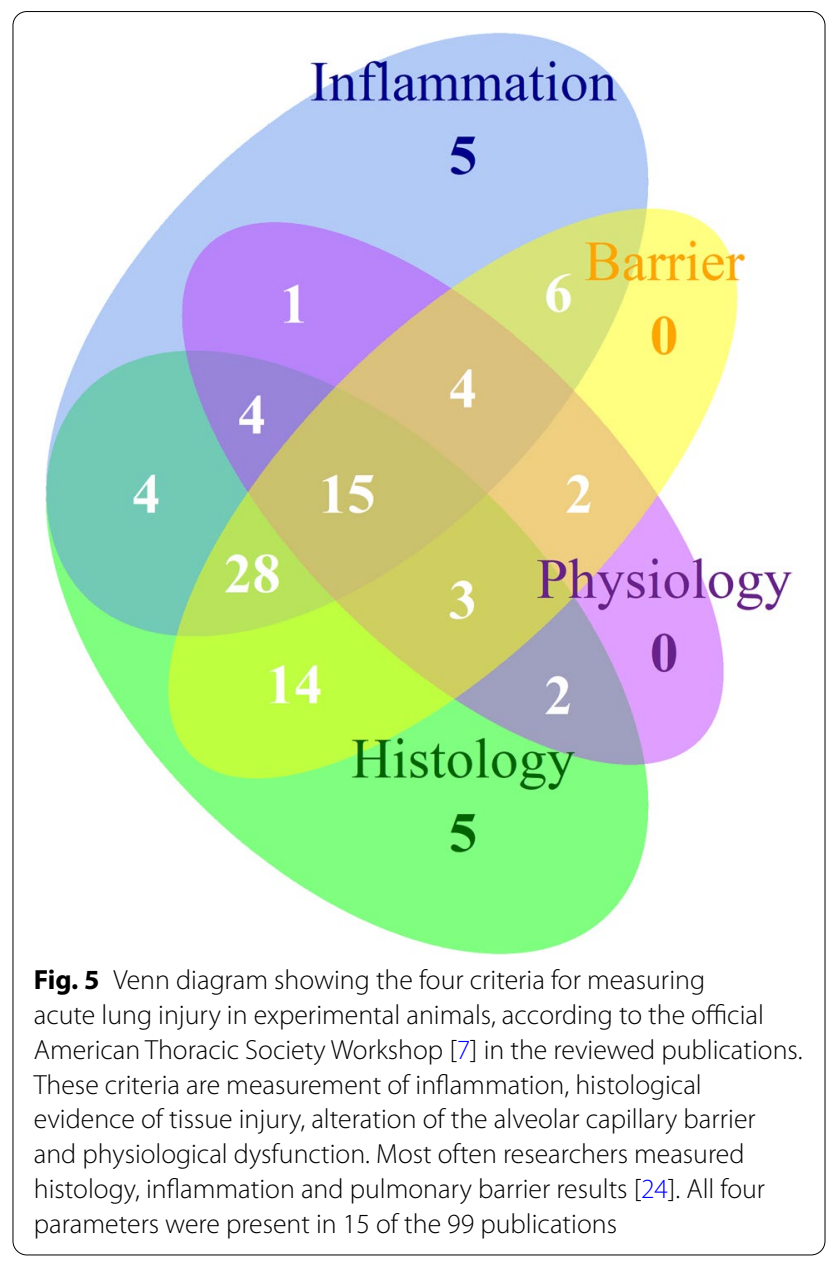

in BALF, along with increases in pro-inflammatory cytokines in lung tissue or BALF. These cytokines were often TNF $\alpha$, IL- 6 and IL-1 $\beta$, although other cytokines were also detected. Approximately two-thirds of the publications reported their findings on inflammatory responses.

Measuring physiological dysfunction was usually in the form of $\mathrm{PaO}_{2} / \mathrm{FIO}_{2}$. But other factors such as lung elasticity were also measured. Thirty-one of 99 publications measured some form of physiological change due to mechanical ventilation.

Symptoms of VILI are hard to distinguish from signs of ARDS. This makes a definition of VILI difficult and it is generically classified alongside ARDS which is defined by acute onset, bilateral opacities that are consistent with pulmonary edema on chest radiographs or chest CT, respiratory failure and decreased $\mathrm{PaO}_{2} / \mathrm{FiO}_{2}$ ratios. Translating these definitions into mouse models is challenging but using the consensus on the main features of ALI in mice from the official American Thoracic Society Workshop [7] could be of benefit. Fifteen of the publications 
showed evidence of lung injury using all of the features (Fig. 5). A further 28 publications presented lung injury using evidence of an inflammatory response, barrier alteration and histology, but no physiology. This is logical given the need for quite expensive and sophisticated equipment to measure physiological parameters in the mice. Histological evidence was evaluated by paraffin embedding of lung tissue and staining. Lung injury scoring was performed in most instances. Various methods were used to measure alteration of the alveolar capillary barrier. These methods include Evans Blue permeability assays, measuring the wet/dry ratio of the lung, and measuring total protein concentration in the BALF. Inflammatory response were measured using cytokine and myeloperoxidase detection assays, most notably, ELISAs and real-time PCRs. Neutrophil infiltration in BALF and lung tissue was also measured. Physiological measurements were usually expressed in terms of $\mathrm{PaO}_{2} /$ $\mathrm{FiO}_{2}$ ratio and heart rate metering.

\section{Conclusions}

This review has revealed a large diversity in parameters used to induce VILI in mouse models over the last 10 years, especially in relation to settings and duration of ventilation required to cause sufficient injury. The variable around the experimental design and the severity and extent of the injury induced creates difficulties in interpretation and comparison of results.

Most often, researchers used the C57BL/6 inbred mouse strain $(>70 \%)$ and the majority preferred male mice. This observation was surprising as the difference between male and female C57BL/6 is most profound in their pre-experimental behaviors. Male C57BL/6 tend to be aggressive and it is more difficult to house them in a single cage. Some male mice are so aggressive that they must be kept alone in cages. However, males tend to be larger and are likely easier to handle when performing tracheotomies. Female C57BL/6 mice, on the other hand, are more docile and can easily be housed in groups of $5-10$ in a single cage. Many animal facilities must take this into consideration as space may not be abundant. Another reason for the bias towards males could be the observation that males have been reported to be more susceptible to VILI and ARDS in the ICU [119]. However, a recent study performed in mice demonstrated that there is only a small difference between genders in response to mechanical ventilation, emphasizing the need to unbias the experimental setup and use both genders, in addition to easing any housing issues raised by male-only studies [120]. Other mouse strains were used in VILI studies, but to a much less extent. The second most popular mouse strain was BALB/c, then the CD-1 and ICR strains. Overall, the choice of mouse strain seems to depend mostly upon availability and ease of breeding, and is less hypothesis driven, which should be considered as the genetic background of mouse strains is highly variable and can affect the statistical outcomes of experiments.

Surprisingly, all ventilator settings differed considerably across the publications. Ventilator output was reported as tidal volume in most of the publications -72 used the term 'tidal volume' and 13 used the term 'pressure'. Fourteen publications reported both tidal volume and pressure. The publications that used tidal volume as their ventilator output nominated tidal volumes of $12-47 \mathrm{~mL} /$ $\mathrm{kg}$ as "injurious", "aggressive" or "high", while "low", "protective", "moderate" and "normal" were used for pressures ranging from 6 to $12 \mathrm{~mL} / \mathrm{kg}$. In the publications that used pressure as a ventilation output, a designation of "low" was used for pressure levels of 8-15 $\mathrm{cm} \mathrm{H}_{2} \mathrm{O}$ and "high" for $20-50 \mathrm{~cm} \mathrm{H}_{2} \mathrm{O}$. The margin at the higher end was considerable.

Respiratory rates differed substantially as well but tended to be lower with higher volumes/pressure. The mechanical strain the lung suffers will be the effect of tidal volume and respiratory rate, which will also affect $\mathrm{PaCO}_{2}$ and circulation due to differences in gas exchange and intrathoracic pressure. It is, however, difficult to define how to keep this within limits that are clinically relevant without frequent blood gas measurements, which are difficult in such small animals. However, such differences further emphasize that with standardized ventilator settings, experimental results will be more comparable.

Whether to set ventilation according to tidal volume/ $\mathrm{kg}$ or airway pressure may be debated. Clinically, use of pressure-regulated ventilator modes has become more frequent as a part of PLV to avoid high airway pressures. In a tracheotomized mouse, the tracheal tube can easily dislodge, and the distal end becomes partially occluded by the tracheal wall producing false high airway pressures, causing the ventilator to deliver less tidal volume. In such circumstances, volume-controlled ventilation might be considered safer to ensure that the set amount of tidal volume is truly administered. This also highlights the importance of monitoring pressure and volume curves while ventilating the animal to ensure appropriate delivery of pressure, volume settings and normal airflow.

The selection of induction and maintenance anesthesia, was also quite varied among the publications. The choice of anesthesia can affect vital signs, and cardiac and respiratory function and thus, is an important aspect of the model $[118,121]$. Most anesthesia selections are acceptable for mice, except for Zoletil, as it severely effects cardiorespiratory depression. The range in doses used could reflect the species, metabolism and gender of the 
mouse in the model. However, doses should be carefully considered to avoid causing unwanted side-effects such as altered blood pressure or obstruction. Ketamine/ xylazine, the barbiturate pentobarbital, and combination anesthesia of ketamine/medetomidine and benzodiazepines/opioids, as used in the studies here, are reported to be effective in mouse respiratory models. Given that body temperature, respiratory and heart rates, and $\mathrm{PaO}_{2}$ are frequently monitored and shown to be relatively stable, comparison between studies should be achievable.

Interestingly, most of the articles do not provide information about monitoring the vital signs of the mouse and thus lack a criterion for assessing if the mouse is alive or not during ventilation, as this can be difficult to assess with the naked eye. Ventilating a deceased mouse could affect the results drastically and so a set of criteria, including, for example, heart rate monitoring with an ECG, to judge at which time point the mouse is considered deceased, is preferable.

This review provides an overview of experiments conducted over the last 10 years on VILI mouse models, especially in relation to settings and duration of ventilation considered appropriate to cause sufficient injury. Our results show a wide variety in these models, causing uncertainty in the amount and degree of VILI produced in each model and therefore difficulties in interpreting results and comparing them between studies. We do not offer a solution to this problem but the information highlighting this here could possibly raise awareness of this situation and encourage a more standardized approach to certain research questions. A consensus needs to be reached regarding ventilator settings, to create a more standardized model in order to facilitate effective transfer of knowledge from in vivo models to the clinical settings.

The confounding factors leading to VILI are difficult to replicate in the mouse model, and here we have highlighted the diversity of parameters that need to be set. Many of the publications we reviewed employed similar methods for inducing VILI, but the intensity of the ventilator settings differed considerably, which makes it difficult to predict which settings are appropriate.

In summary, stringent guidelines and a standardized model is needed to be able to effectively transfer the knowledge from the in vivo model to the clinical setting.

\footnotetext{
Abbreviations

ARDS: Acute respiratory distress syndrome; BALF: Bronchoalveolar lavage fluid; CPAD: Cyclical pressure air-liquid interface device; CT: Computed tomography; $\mathrm{ECCO}_{2} \mathrm{R}$ : Extracorporeal $\mathrm{CO}_{2}$ removal; ECG: Electrocardiogram; ECMO: Extracorporeal membrane oxygenation; FRC: Functional residual capacity; $\mathrm{FlO}_{2}$ : Fraction of inspired oxygen; H\&E: Hemotoxylin and eosin; ICU: Intensive care unit; IL: Interleukin; MV: Mechanical ventilation; $\mathrm{PaCO}_{2}$ : Partial pressure of carbon dioxide; $\mathrm{PaO}_{2}$ : Partial pressure of oxygen; PEEP: Positive end-expiratory pressure; PLV: Protective lung ventilation; TNF: Tumor necrosis factor; VILI: Ventilator-induced lung injury.
}

\section{Supplementary Information}

The online version contains supplementary material available at https://doi. org/10.1186/s42826-021-00108-x.

Additional file 1. Supplemental table 1.

\section{Acknowledgements}

The authors would like to thank Prof. Michael J. Parnham and Friðrik Rúnar Garðarsson for their valuable comments and insights while writing this review.

\section{Authors' contributions}

JPJ: conceptualization; data mining; translation of data; writing of original draft; final review and editing. SI: conceptualization; translation of data; final review and editing; JK: methodology; translation of data; final review and editing; TG: translation of data; final writing manuscript; final review and editing; SK: supervision; translation of data; writing manuscript; final review and editing. All authors read and approved the final manuscript.

Funding

This research was supported by grants from Landspitali research fund.

Availability of data and materials

All articles reviewed here were found using a PubMed search with the search title "ventilator induced lung injury mouse model", filtering the publication year from 2010 to 2020. From the 372 matching hits, we concentrated on models where mice were mechanically ventilated, leaving a pool of 99 publications.

\section{Declarations}

Ethical approval and consent to participate Not applicable.

\section{Consent for publication}

Not applicable.

\section{Competing interests}

The authors declare that they have no competing interests.

\section{Author details}

${ }^{1}$ Stem Cell Research Unit, BioMedical Center, School of Health Sciences, University of Iceland, Reykjavik, Iceland. ${ }^{2}$ Department of Laboratory Hematology, Landspitali-University Hospital, Reykjavik, Iceland. ${ }^{3}$ Faculty of Nursing, University of Iceland, Reykjavik, Iceland. ${ }^{4}$ EpiEndo Pharmaceuticals, Seltjarnarnes, Iceland. Intensive Care Unit, Landspitali-University Hospital, Reykjavik, Iceland.

Received: 19 August 2021 Accepted: 20 October 2021

Published online: 29 October 2021

\section{References}

1. Acute Respiratory Distress Syndrome Network, Brower RG, Matthay MA, Morris A, Schoenfeld D, Thompson BT, et al. Ventilation with lower tidal volumes as compared with traditional tidal volumes for acute lung injury and the acute respiratory distress syndrome. N Engl J Med. 2000;342(18):1301-8.

2. Beitler JR, Malhotra A, Thompson BT. Ventilator-induced lung injury. Clin Chest Med. 2016;37(4):633-46

3. Curley GF, Laffey JG, Zhang H, Slutsky AS. Biotrauma and ventilatorinduced lung injury: clinical implications. Chest. 2016;150(5):1109-17.

4. Miller AJ, Spence JR. In vitro models to study human lung development, disease and homeostasis. Physiology (Bethesda). 2017;32(3):246-60.

5. Joelsson JP, Myszor IT, Arason AJ, Ingthorsson S, Cherek P, Windels GS, et al. Innovative in vitro method to study ventilator induced lung injury. Altex. 2019;36(4):634-42. 
6. Joelsson JP, Myszor IT, Sigurdsson S, Lehmann F, Page C, Gudmundsson $\mathrm{GH}$, et al. Azithromycin has lung barrier protective effects in a cell model mimicking ventilator-induced lung injury. Altex. 2020;37(4):545-60.

7. Matute-Bello G, Downey G, Moore BB, Groshong SD, Matthay MA, Slutsky AS, et al. An official American Thoracic Society workshop report: features and measurements of experimental acute lung injury in animals. Am J Respir Cell Mol Biol. 2011;44(5):725-38.

8. Chess PR, Benson RP, Maniscalco WM, Wright TW, O'Reilly MA, Johnston CJ. Murine mechanical ventilation stimulates alveolar epithelial cell proliferation. Exp Lung Res. 2010;36(6):331-41.

9. Chun CD, Liles WC, Frevert CW, Glenny RW, Altemeier WA. Mechanical ventilation modulates toll-like receptor-3-induced lung inflammation via a MyD88-dependent, TLR4-independent pathway: a controlled animal study. BMC Pulm Med. 2010;10:57.

10. Faller S, Ryter SW, Choi AM, Loop T, Schmidt R, Hoetzel A. Inhaled hydrogen sulfide protects against ventilator-induced lung injury. Anesthesiology. 2010;113(1):104-15.

11. Fanelli V, Puntorieri V, Assenzio B, Martin EL, Elia V, Bosco M, et al. Pulmonary-derived phosphoinositide 3-kinase gamma (PI3KY) contributes to ventilator-induced lung injury and edema. Intensive Care Med. 2010;36(11):1935-45.

12. Li H, Su X, Yan X, Wasserloos K, Chao W, Kaynar AM, et al. Toll-like receptor 4-myeloid differentiation factor 88 signaling contributes to ventilator-induced lung injury in mice. Anesthesiology. 2010;113(3):619-29.

13. Müller HC, Witzenrath M, Tschernig T, Gutbier B, Hippenstiel S, Santel $A$, et al. Adrenomedullin attenuates ventilator-induced lung injury in mice. Thorax. 2010;65(12):1077-84.

14. Fu P, Murley JS, Grdina DJ, Birukova AA, Birukov KG. Induction of cellular antioxidant defense by amifostine improves ventilator-induced lung injury. Crit Care Med. 2011;39(12):2711-21.

15. González-López A, Astudillo A, García-Prieto E, Fernández-García MS, López-Vázquez A, Batalla-Solís E, et al. Inflammation and matrix remodeling during repair of ventilator-induced lung injury. Am J Physiol Lung Cell Mol Physiol. 2011;301(4):L500-9.

16. Gurkan OU, He C, Zielinski R, Rabb H, King LS, Dodd-o JM, et al. Interleukin-6 mediates pulmonary vascular permeability in a two-hit model of ventilator-associated lung injury. Exp Lung Res. 2011;37(10):575-84.

17. Li LF, Huang CC, Liu YY, Lin HC, Kao KC, Yang CT, et al. Hydroxyethyl starch reduces high stretch ventilation-augmented lung injury via vascular endothelial growth factor. TransI Res. 2011;157(5):293-305.

18. Li L-F, Yang CT, Huang CC, Liu YY, Kao KC, Lin HC. Low-molecular-weight heparin reduces hyperoxia-augmented ventilator-induced lung injury via serine/threonine kinase-protein kinase B. Respir Res. 2011;12(1):90.

19. Rentsendorj O, Damarla M, Aggarwal NR, Choi J-Y, Johnston L, D'Alessio $F R$, et al. Knockdown of lung phosphodiesterase $2 \mathrm{~A}$ attenuates alveolar inflammation and protein leak in a two-hit mouse model of acute lung injury. Am J Physiol Lung Cell Mol Physiol. 2011;301(2):L161-70.

20. dos Santos CC, Shan Y, Akram A, Slutsky AS, Haitsma JJ. Neuroimmune regulation of ventilator-induced lung injury. Am J Respir Crit Care Med. 2011:183(4):471-82

21. Seah AS, Grant KA, Aliyeva M, Allen GB, Bates JHT. Quantifying the roles of tidal volume and PEEP in the pathogenesis of ventilator-induced lung injury. Ann Biomed Eng. 2011;39(5):1505-16.

22. Takahashi K, Saha D, Shattino I, Pavlov VI, Stahl GL, Finnegan P, et al. Complement 3 is involved with ventilator-induced lung injury. Int Immunopharmacol. 2011;11(12):2138-43.

23. Bertok S, Wilson MR, Morley PJ, de Wildt R, Bayliffe A, Takata M. Selective inhibition of intra-alveolar p55 TNF receptor attenuates ventilatorinduced lung injury. Thorax. 2012;67(3):244-51.

24. Cabrera-Benítez NE, Parotto M, Post M, Han B, Spieth PM, Cheng W-E, et al. Mechanical stress induces lung fibrosis by epithelial-mesenchymal transition. Crit Care Med. 2012;40(2):510-7.

25. Faller S, Foeckler M, Strosing KM, Spassov S, Ryter SW, Buerkle H, et al. Kinetic effects of carbon monoxide inhalation on tissue protection in ventilator-induced lung injury. Lab Invest. 2012;92(7):999-1012.

26. Hoogendijk AJ, Kuipers MT, van der Poll T, Schultz MJ, Wieland CW. Cyclin-dependent kinase inhibition reduces lung damage in a mouse model of ventilator-induced lung injury. Shock. 2012;38(4):375-80.
27. Li LF, Kao KC, Yang CT, Huang CC, Liu YY. Ethyl pyruvate reduces ventilation-induced neutrophil infiltration and oxidative stress. Exp Biol Med (Maywood). 2012;237(6):720-7.

28. Makena PS, Gorantla VK, Ghosh MC, Bezawada L, Kandasamy K, Balazs $L$, et al. Deletion of apoptosis signal-regulating kinase-1 prevents ventilator-induced lung injury in mice. Am J Respir Cell Mol Biol. 2012;46(4):461-9.

29. Pires KM, Melo AC, Lanzetti M, Casquilho NV, Zin WA, Porto LC, et al. Low tidal volume mechanical ventilation and oxidative stress in healthy mouse lungs. J Bras Pneumol. 2012;38(1):98-104.

30. Real JM, Spilborghs GM, Morato-Marques M, de Moura RP, Negri EM, Camargo AA, et al. Pentraxin 3 accelerates lung injury in high tidal volume ventilation in mice. Mol Immunol. 2012;51(1):82-90.

31. Siegl S, Uhlig S. Using the one-lung method to link p38 to pro-inflammatory gene expression during overventilation in C57BL/6 and BALB/C mice. PLoS ONE. 2012;7(7):e41464.

32. Vaporidi K, Vergadi E, Kaniaris E, Hatziapostolou M, Lagoudaki E, Georgopoulos D, et al. Pulmonary microRNA profiling in a mouse model of ventilator-induced lung injury. Am J Physiol Lung Cell Mol Physiol. 2012;303(3):L199-207.

33. Vlaar APJ, Kuipers MT, Hofstra JJ, Wolthuis EK, Wieland CW, Roelofs JJTH, et al. Mechanical ventilation and the titer of antibodies as risk factors for the development of transfusion-related lung injury. Crit Care Res Pract. 2012:2012:720950.

34. Wilson MR, Patel BV, Takata M. Ventilation with "clinically relevant" high tidal volumes does not promote stretch-induced injury in the lungs of healthy mice. Crit Care Med. 2012;40(10):2850-7.

35. Wolthuis EK, Vlaar APJ, Choi G, Roelofs JJTH, Levi M, Juffermans NP, et al. Relative tissue factor deficiency attenuates ventilator-induced coagulopathy but does not protect against ventilator-induced lung injury in mice. Crit Care Res Pract. 2012;2012:130410.

36. Amado-Rodríguez L, González-López A, López-Alonso I, Aguirre A, Astudillo A, Batalla-Solís E, et al. Anti-inflammatory effects of clarithromycin in ventilator-induced lung injury. Respir Res. 2013;14(1):52.

37. Hegeman MA, Hemmes SNT, Kuipers MT, Bos LDJ, Jongsma G, Roelofs JJTH, et al. The extent of ventilator-induced lung injury in mice partly depends on duration of mechanical ventilation. Crit Care Res Pract. 2013;2013:435236.

38. Hegeman MA, Hennus MP, Cobelens PM, Kavelaars A, Jansen NJG, Schultz MJ, et al. Dexamethasone attenuates VEGF expression and inflammation but not barrier dysfunction in a murine model of ventilator-induced lung injury. PLoS ONE. 2013:8(2):e57374.

39. Koeppen M, McNamee EN, Brodsky KS, Aherne CM, Faigle M, Downey GP, et al. Detrimental role of the airway mucin Muc5ac during ventilator-induced lung injury. Mucosal Immunol. 2013;6(4):762-75

40. Li LF, Chu PH, Hung CY, Kao WW, Lin MC, Liu YY, et al. Lumican regulates ventilation-induced epithelial-mesenchymal transition through extracelluar signal-regulated kinase pathway. Chest. 2013;143(5):1252-60.

41. López-Alonso I, Aguirre A, González-López A, Fernández ÁF, AmadoRodríguez L, Astudillo A, et al. Impairment of autophagy decreases ventilator-induced lung injury by blockade of the NF-KB pathway. Am J Physiol Lung Cell Mol Physiol. 2013;304(12):L844-52.

42. Meliton AY, Muñoz NM, Meliton LN, Birukova AA, Leff AR, Birukov KG. Mechanical induction of group V phospholipase A2 causes lung inflammation and acute lung injury. Am J Physiol Lung Cell Mol Physiol. 2013;304(10):L689-700.

43. Ratner V, Sosunov SA, Niatsetskaya ZV, Utkina-Sosunova IV, Ten VS, Mechanical ventilation causes pulmonary mitochondrial dysfunction and delayed alveolarization in neonatal mice. Am J Respir Cell Mol Biol. 2013:49(6):943-50.

44. Saha D, Takahashi K, de Prost N, Winkler T, Pinilla-Vera M, Baron RM, et al. Micro-autoradiographic assessment of cell types contributing to 2-deoxy-2-[ ${ }^{8}$ F]Fluoro-D-glucose uptake during ventilator-induced and endotoxemic lung injury. Mol Imaging Biol. 2013:15(1):19-27.

45. Goldman JL, Sammani S, Kempf C, Saadat L, Letsiou E, Wang T, et al. Pleiotropic effects of interleukin-6 in a "two-hit" murine model of acute respiratory distress syndrome. Pulm Circ. 2014;4(2):280-8.

46. Hennus MP, Bont $L$, Jansen NJ, van Vught AJ. Tidal volume drives inflammation during mechanical ventilation for viral respiratory infection. Pediatr Crit Care Med. 2014;15(1):e27-31. 
47. Kaniaris E, Vaporidi K, Vergadi E, Theodorakis EE, Kondili E, Lagoudaki E, et al. Genetic and pharmacologic inhibition of Tpl2 kinase is protective in a mouse model of ventilator-induced lung injury. Intensive Care Med Exp. 2014;2(1):15.

48. Kuipers MT, Aslami H, Tuinman PR, Tuip-de Boer AM, Jongsma G, van der Sluijs KF, et al. The receptor for advanced glycation end products in ventilator-induced lung injury. Intensive Care Med Exp. 2014;2(1):22.

49. Moreno-Vinasco L, Quijada H, Sammani S, Siegler J, Letsiou E, Deaton $R$, et al. Nicotinamide phosphoribosyltransferase inhibitor is a novel therapeutic candidate in murine models of inflammatory lung injury. Am J Respir Cell Mol Biol. 2014;51(2):223-8.

50. Otulakowski G, Engelberts D, Gusarova GA, Bhattacharya J, Post M Kavanagh BP. Hypercapnia attenuates ventilator-induced lung injury via a disintegrin and metalloprotease-17. J Physiol. 2014;592(20):4507-21.

51. Shiga Y, Sugamata R, Iwamura C, Nagao T, Zao J, Kawakami K, et al. Effect of invariant natural killer T cells with IL-5 and activated IL-6 receptor in ventilator-associated lung injury in mice. Exp Lung Res. 2014;40(1):1-11

52. Sun X, Elangovan VR, Mapes B, Camp SM, Sammani S, Saadat $L$, et al. The NAMPT promoter is regulated by mechanical stress, signal transducer and activator of transcription 5, and acute respiratory distress syndrome-associated genetic variants. Am J Respir Cell Mol Biol. 2014;51(5):660-7.

53. Dong WW, Liu YJ, Lv Z, Mao YF, Wang YW, Zhu XY, et al. Lung endothelial barrier protection by resveratrol involves inhibition of HMGB1 release and HMGB1-induced mitochondrial oxidative damage via an Nrf2dependent mechanism. Free Radic Biol Med. 2015:88:404-16.

54. Englert JA, Macias AA, Amador-Munoz D, Pinilla Vera M, Isabelle C, Guan $J$, et al. Isoflurane ameliorates acute lung injury by preserving epithelial tight junction integrity. Anesthesiology. 2015;123(2):377-88.

55. Li LF, Lee CS, Liu YY, Chang CH, Lin CW, Chiu LC, et al. Activation of SrCdependent Smad3 signaling mediates the neutrophilic inflammation and oxidative stress in hyperoxia-augmented ventilator-induced lung injury. Respir Res. 2015;16(1):112.

56. Manitsopoulos N, Orfanos SE, Kotanidou A, Nikitopoulou I, Siempos I, Magkou C, et al. Inhibition of HMGCoA reductase by simvastatin protects mice from injurious mechanical ventilation. Respir Res. 2015;16(1):24

57. Yildiz C, Palaniyar N, Otulakowski G, Khan MA, Post M, Kuebler WM, et al. Mechanical ventilation induces neutrophil extracellular trap formation. Anesthesiology. 2015;122(4):864-75.

58. Zambelli V, Bellani G, Amigoni M, Grassi A, Scanziani M, Farina F, et al. The effects of exogenous surfactant treatment in a murine model of two-hit lung injury. Anesth Analg. 2015;120(2):381-8.

59. Li LF, Chang YL, Chen NH, Wang CY, Chang GJ, Lin MC, et al. Inhibition of Src and forkhead box $\mathrm{O} 1$ signaling by induced pluripotent stem-cell therapy attenuates hyperoxia-augmented ventilator-induced diaphragm dysfunction. Transl Res. 2016;173:131-47.e1

60. Scheiermann J, Klinman DM. Suppressive oligonucleotides inhibit inflammation in a murine model of mechanical ventilator induced lung injury. J Thorac Dis. 2016:8(9):2434-43.

61. Shi CS, Huang TH, Lin CK, Li JM, Chen MH, Tsai ML, et al. VEGF production by Ly6C ${ }^{\text {thigh }}$ monocytes contributes to ventilator-induced lung injury. PLOS ONE. 2016;11(10):e0165317.

62. Strosing KM, Faller S, Gyllenram V, Engelstaedter $H$, Buerkle $H$, Spassov $S$, et al. Inhaled anesthetics exert different protective properties in a mouse model of ventilator-induced lung injury. Anesth Analg. 2016:123(1):143-51.

63. Hepokoski M, Englert JA, Baron RM, Crotty-Alexander LE, Fuster MM, Beitler JR, et al. Ventilator-induced lung injury increases expression of endothelial inflammatory mediators in the kidney. Am J Physiol Renal Physiol. 2017;312(4):F654-60.

64. Lex D, Uhlig S. One-hit models of ventilator-induced lung injury: benign inflammation versus inflammation as a by-product. Anesthesiology. 2017;126(5):909-22.

65. Michalick L, Erfinanda L, Weichelt U, van der Giet M, Liedtke W, Kuebler WM. Transient receptor potential vanilloid 4 and serum glucocorticoidregulated kinase 1 are critical mediators of lung injury in overventilated mice in vivo. Anesthesiology. 2017;126(2):300-11.

66. Pan S, Fei A, Jing L, Zhang X, Gao C. Increased circulating endothelial microparticles associated with PAK4 play a key role in ventilation-induced lung injury process. Biomed Res Int. 2017;2017:4902084

67. Spassov SG, Donus R, Ihle PM, Engelstaedter H, Hoetzel A, Faller S. Hydrogen sulfide prevents formation of reactive oxygen species through PI3K/Akt signaling and limits ventilator-induced lung injury. Oxid Med Cell Longev. 2017;2017:3715037.

68. Wilson MR, Petrie JE, Shaw MW, Hu C, Oakley CM, Woods SJ, et al. Highfat feeding protects mice from ventilator-induced lung injury, via neutrophil-independent mechanisms. Crit Care Med. 2017;45(8):e831-9.

69. Xiao R, Chen R. Neutrophil gelatinase-associated lipocalin as a potential novel biomarker for ventilator-associated lung injury. Mol Med Rep. 2017;15(6):3535-40.

70. Ding $X$, Tong $Y$, Jin S, Chen Z, Li T, Billiar TR, et al. Mechanical ventilation enhances extrapulmonary sepsis-induced lung injury: role of WISP1av 35 integrin pathway in TLR4-mediated inflammation and injury. Crit Care. 2018;22(1):302.

71. Guivarch E, Voiriot G, Rouzé A, Kerbrat S, Tran Van Nhieu J, Montravers $P$, et al. Pulmonary effects of adjusting tidal volume to actual or ideal body weight in ventilated obese mice. Sci Rep. 2018;8(1):6439.

72. Hamlington $\mathrm{KL}$, Smith BJ, Dunn CM, Charlebois CM, Roy GS, Bates JHT. Linking lung function to structural damage of alveolar epithelium in ventilator-induced lung injury. Respir Physiol Neurobiol. 2018;255:22-9.

73. López-Alonso I, Blázquez-Prieto J, Amado-Rodríguez L, González-López A, Astudillo A, Sánchez M, et al. Preventing loss of mechanosensation by the nuclear membranes of alveolar cells reduces lung injury in mice during mechanical ventilation. Sci Transl Med. 2018;10(456):eaam7598.

74. Nagre N, Cong X, Ji HL, Schreiber JM, Fu H, Pepper I, et al. Inhaled TRIM72 protein protects ventilation injury to the lung through injuryguided cell repair. Am J Respir Cell Mol Biol. 2018;59(5):635-47.

75. Siempos II, Ma KC, Imamura M, Baron RM, Fredenburgh LE, Huh JW, et al. RIPK3 mediates pathogenesis of experimental ventilator-induced lung injury. JCI Insight. 2018;3(9):e97102.

76. Suryadevara V, Fu P, Ebenezer DL, Berdyshev E, Bronova IA, Huang LS, et al. Sphingolipids in ventilator induced lung injury: role of sphingosine-1-phosphate lyase. Int J Mol Sci. 2018;19(1):114.

77. Wan B, Xu WJ, Zhan P, Jin JJ, Xi GM, Chen MZ, et al. Topotecan alleviates ventilator-induced lung injury via NF-kB pathway inhibition. Cytokine. 2018:110:381-8.

78. Wang X, Luo B, Lu Y, Pang D, Zheng J, Mo J, et al. The triggering receptor expressed by myeloid cells-1 activates TLR4-MyD88-NF-kB-dependent signaling to aggravate ventilation-induced lung inflammation and injury in mice. Cell Tissue Res. 2018;374(1):137-48.

79. Wienhold SM, Macrì M, Nouailles G, Dietert K, Gurtner C, Gruber AD, et al. Ventilator-induced lung injury is aggravated by antibiotic mediated microbiota depletion in mice. Crit Care. 2018;22(1):282.

80. Xu B, Wang Y, Li X, Mao Y, Deng X. RNA-sequencing analysis of aberrantly expressed long non-coding RNAs and mRNAs in a mouse model of ventilator-induced lung injury. Mol Med Rep. 2018;18(1):882-92.

81. Zheng J, Huang Y, Islam D, Wen XY, Wu S, Streutker C, et al. Dual effects of human neutrophil peptides in a mouse model of pneumonia and ventilator-induced lung injury. Respir Res. 2018;19(1):190.

82. An X, Sun X, Yang X, Liu D, Hou Y, Chen H, et al. Oxidative stress promotes ventilator-induced lung injury through activating NLRP3 inflammasome and TRPM2 channel. Artif Cells Nanomed Biotechnol. 2019;47(1):3448-55.

83. Fang M, Fan S, Yao X, Liu N, Gao J, Wang Z, et al. Transfection of Sox 11 plasmid alleviates ventilator-induced lung injury via Sox 11 and FAK. Biochem Biophys Res Commun. 2019;512(2):182-8.

84. Feng Z, Wang JW, Wang Y, Dong WW, Xu ZF. Propofol protects lung endothelial barrier function by suppression of high-mobility group box 1 (HMGB1) release and mitochondrial oxidative damage catalyzed by HMGB1. Med Sci Monit. 2019;25:3199-211.

85. Huang $H$, Feng $H$, Zhuge D. M1 macrophage activated by notch signal pathway contributed to ventilator-induced lung injury in chronic obstructive pulmonary disease model. J Surg Res. 2019;244:358-67.

86. Huang TH, Fang PH, Li JM, Ling HY, Lin CM, Shi CS. Cyclooxygenase-2 activity regulates recruitment of VEGF-secreting Ly6C(high) monocytes in ventilator-induced lung injury. Int J Mol Sci. 2019;20(7):1771.

87. Liu G, Gu C, Liu M, Liu H, Wang D, Liu X, et al. Protective role of p120catenin on mitochondria by inhibiting NLRP3 in ventilator-induced lung injury. J Cell Mol Med. 2019;23(11):7360-71. 
88. Liu Q, Xie W, Wang Y, Chen S, Han J, Wang L, et al. JAK2/STAT1-mediated HMGB1 translocation increases inflammation and cell death in a ventilator-induced lung injury model. Lab Investig. 2019;99(12):1810-21.

89. Mellenthin MM, Seong SA, Roy GS, Bartolák-Suki E, Hamlington KL, Bates JHT, et al. Using injury cost functions from a predictive singlecompartment model to assess the severity of mechanical ventilatorinduced lung injuries. J Appl Physiol (1985). 2019;127(1):58-70.

90. Szabari MV, Takahashi K, Feng Y, Locascio JJ, Chao W, Carter EA, et al. Relation between respiratory mechanics, inflammation, and survival in experimental mechanical ventilation. Am J Respir Cell Mol Biol. 2019;60(2):179-88.

91. Wang Y, Gao TT, Xu DF, Zhu XY, Dong WW, Lv Z, et al. Upregulation of sphingosine kinase 1 contributes to ventilator-associated lung injury in a two-hit model. Int J Mol Med. 2019:44(6):2077-90.

92. Xia YF, Chang J, Yang JF, Ouyang W, Pitt B, Billiar T, et al. Non-canonical Wnt signaling contributes to ventilator-induced lung injury through upregulation of WISP1 expression. Int J Mol Med. 2019;43(3):1217-28.

93. Xu CF, Liu YJ, Wang Y, Mao YF, Xu DF, Dong WW, et al. Downregulation of R-Spondin 1 contributes to mechanical stretch-induced lung injury. Crit Care Med. 2019;47(7):e587-96.

94. Zhang NN, Zhang Y, Wang L, Xia JG, Liang ST, Wang Y, et al. Expression profiling analysis of long noncoding RNAs in a mouse model of ventilator-induced lung injury indicating potential roles in inflammation. J Cell Biochem. 2019;120(7):11660-79.

95. Fang M, Liu N, Yao X, Xu T, Wang Z. Enhancement of FAK alleviates ventilator-induced alveolar epithelial cell injury. Sci Rep. 2020;10(1):419.

96. Li LF, Liu YY, Lin SW, Chang CH, Chen NH, Hung CY, et al. Low-molecularweight heparin reduces ventilation-induced lung injury through hypoxia inducible factor-1a in a murine endotoxemia model. Int J Mol Sci. 2020;21(9):3097

97. Liu H, Gu C, Liu M, Liu G, Wang Y. NEK7 mediated assembly and activation of NLRP3 inflammasome downstream of potassium efflux in ventilator-induced lung injury. Biochem Pharmacol. 2020;177:113998.

98. Ren R, Ruan Z, Ding H, Du J, Yu W. Phosphoproteome profiling provides insight into the mechanisms of ventilator-induced lung injury. Exp Ther Med. 2020;19(6):3627-33.

99. Ruan H, Li W, Wang J, Chen G, Xia B, Wang Z, et al. Propofol alleviates ventilator-induced lung injury through regulating the Nrf2/NLRP3 signaling pathway. Exp Mol Pathol. 2020;114:104427.

100. Smith BJ, Roy GS, Cleveland A, Mattson C, Okamura K, Charlebois $\mathrm{CM}$, et al. Three alveolar phenotypes govern lung function in murine ventilator-induced lung injury. Front Physiol. 2020;11:660.

101. Wan B, Xu WJ, Chen MZ, Sun SS, Jin JJ, Lv YL, et al. Geranylgeranyl diphosphate synthase 1 knockout ameliorates ventilator-induced lung injury via regulation of TLR2/4-AP-1 signaling. Free Radic Biol Med. 2020;147:159-66.

102. Wang $Y$, Yang $Y$, Chen $L$, Xiong W, Song L, Li B, et al. Death-associated protein kinase 1 mediates ventilator-induced lung injury in mice by promoting alveolar epithelial cell apoptosis. Anesthesiology. 2020;133(4):905-18

103. Yen S, Song Y, Preissner M, Bennett E, Wilson R, Pavez M, et al. The proteomic response is linked to regional lung volumes in ventilatorinduced lung injury. J Appl Physiol (1985). 2020;129(4):837-45.

104. Piao L, Park HJ, Seo EH, Kim TW, Shin JK, Kim SH. The effects of endoplasmic reticulum stress on the expression of exosomes in ventilatorinduced lung injury. Ann Palliat Med. 2021;10(2):1050-8.

105. Veskemaa L, Graw JA, Pickerodt PA, Taher M, Boemke W, GonzálezLópez A, et al. Tert-butylhydroquinone augments Nrf2-dependent resilience against oxidative stress and improves survival of ventilatorinduced lung injury in mice. Am J Physiol Lung Cell Mol Physiol. 2021:320(1):L17-28

106. Zhang C, Hu S, Zosky GR, Wei X, Shu S, Wang D, et al. Paracoxib alleviates ventilator-induced lung injury through functional modulation of lung-recruited CD11 bloLy6Chi monocytes. Shock. 2021;55(2):236-43.

107. Song HK, Hwang DY. Use of C57BL/6N mice on the variety of immunological researches. Lab Anim Res. 2017;33(2):119-23.

108. Schulz H, Johner C, Eder G, Ziesenis A, Reitmeier P, Heyder J, et al. Respiratory mechanics in mice: strain and sex specific differences. Acta Physiol Scand. 2002;174(4):367-75.

109. Medina D. Of mice and women: a short history of mouse mammary cancer research with an emphasis on the paradigms inspired by the transplantation method. Cold Spring Harb Perspect Biol. 2010;2(10):a004523.

110. Johnson M. Laboratory mice and rats. Mater Methods. 2012;2:113. https://doi.org/10.13070/mm.en.2.113. https://www.labome.com/ method/Laboratory-Mice-and-Rats.html.

111. Pham T, Brochard LJ, Slutsky AS. Mechanical ventilation: state of the art. Mayo Clin Proc. 2017;92(9):1382-400.

112. Pelosi P, Ball L, Barbas CSV, Bellomo R, Burns KEA, Einav S, et al. Personalized mechanical ventilation in acute respiratory distress syndrome. Crit Care. 2021;25(1):250.

113. Fan E, Del Sorbo L, Goligher EC, Hodgson CL, Munshi L, Walkey AJ, et al. An official American Thoracic Society/European Society of Intensive Care Medicine/Society of Critical Care Medicine Clinical Practice Guideline: mechanical ventilation in adult patients with acute respiratory distress syndrome. Am J Respir Crit Care Med. 2017;195(9):1253-63.

114. Meyer NJ, Gattinoni L, Calfee CS. Acute respiratory distress syndrome. Lancet. 2021;398(10300):622-37.

115. Chacko B, Peter JV, Tharyan P, John G, Jeyaseelan L. Pressure-controlled versus volume-controlled ventilation for acute respiratory failure due to acute lung injury (ALI) or acute respiratory distress syndrome (ARDS). Cochrane Database Syst Rev. 2015;1:CD008807.

116. Walkey AJ, Sorbo LD, Hodgson CL, Adhikari NKJ, Wunsch H, Meade MO, et al. Higher PEEP versus lower PEEP strategies for patients with acute respiratory distress syndrome. A systematic review and meta-analysis. Ann Am Thorac Soc. 2017;14(Supplement_4):S297-303.

117. Wilson M, Takata M. Mechanical ventilation in mice: does longer equal better? Am J Respir Cell Mol Biol. 2019;60(2):137-8.

118. Gargiulo S, Greco A, Gramanzini M, Esposito S, Affuso A, Brunetti A, et al. Mice anesthesia, analgesia, and care, part I: anesthetic considerations in preclinical research. ILAR J. 2012;53(1):E55-69.

119. Mahmood K, Eldeirawi K, Wahidi MM. Association of gender with outcomes in critically ill patients. Crit Care. 2012;16(3):R92.

120. López-Alonso I, Amado-Rodriguez L, López-Martínez C, Huidobro C, Albaiceta GM. Sex susceptibility to ventilator-induced lung injury. Intensive Care Med Exp. 2019;7(1):7.

121. Tsukamoto A, Serizawa K, Sato R, Yamazaki J, Inomata T. Vital signs monitoring during injectable and inhalant anesthesia in mice. Exp Anim. 2015;64(1):57-64

\section{Publisher's Note}

Springer Nature remains neutral with regard to jurisdictional claims in published maps and institutional affiliations. 